University of Nebraska - Lincoln

DigitalCommons@University of Nebraska - Lincoln

\title{
Enhanced Efficiency Fertilizers: Effect on Nitrous Oxide Emissions in lowa
}

Timothy B. Parkin

USDA-ARS, tim.parkin@ars.usda.gov

Jerry L. Hatfield

USDA-ARS, jerry.hatfield@ars.usda.gov

Follow this and additional works at: https://digitalcommons.unl.edu/usdaarsfacpub

Parkin, Timothy B. and Hatfield, Jerry L., "Enhanced Efficiency Fertilizers: Effect on Nitrous Oxide Emissions in lowa" (2013). Publications from USDA-ARS / UNL Faculty. 1353.

https://digitalcommons.unl.edu/usdaarsfacpub/1353

This Article is brought to you for free and open access by the U.S. Department of Agriculture: Agricultural Research Service, Lincoln, Nebraska at DigitalCommons@University of Nebraska - Lincoln. It has been accepted for inclusion in Publications from USDA-ARS / UNL Faculty by an authorized administrator of DigitalCommons@University of Nebraska - Lincoln. 


\title{
Enhanced Efficiency Fertilizers: Effect on Nitrous Oxide Emissions in lowa
}

\author{
Timothy B. Parkin* and Jerry L. Hatfield
}

\begin{abstract}
Fertilizer application in crop production agriculture is a major factor influencing soil emissions of the greenhouse gas $\mathrm{N}_{2} \mathrm{O}$. Enhanced efficiency fertilizers (EEFs) have the potential to decrease $\mathrm{N}_{2} \mathrm{O}$ emissions by improving the synchrony between soil $\mathrm{N}$ supply and crop $\mathrm{N}$ demand. This study was conducted to compare the effects of $\mathrm{N}_{2} \mathrm{O}$ emissions from soil cropped to corn (Zea mays L.) and EEFs and conventional fertilizers. During a 3-yr period, growing-season $\mathrm{N}_{2} \mathrm{O}$ emissions were quantified in unfertilized check plots and plots fertilized with urea- $\mathrm{NH}_{4} \mathrm{NO}_{3}$ (UAN), UAN containing the urease and nitrification stabilizer AgrotainPlus (UAN+Ag), a stabilized urea containing urease and nitrification inhibitors (SuperU), and a controlled-release polymer-coated urea (ESN). In the third year of the study, conventional urea and an additional fertilizer formulation, Nutrisphere, were evaluated. We observed no reductions in cumulative seasonal $\mathrm{N}_{2} \mathrm{O}$ emissions from treatments fertilized with the EEFs in any of the study years. Generally, $\mathrm{N}_{2} \mathrm{O}$ emissions were significantly higher than emissions from the check (no fertilizer) treatment. There were no differences among fertilizer types except in 2009 when the ESN treatment had significantly higher emissions than the check, UAN, and UAN+Ag treatments. Our results indicate that, due to the episodic nature of $\mathrm{N}_{2} \mathrm{O}$ emissions induced by rainfall events, reduction of $\mathrm{N}_{2} \mathrm{O}$ emissions through the use of EEFs may be limited in rainfed regions.
\end{abstract}

$\mathrm{N}$ ITROUS OXIDE FROM agricultural cropping systems is responsible for approximately $71 \%$ of the U.S. $\mathrm{N}_{2} \mathrm{O}$ emissions (USEPA, 2013). The impacts of agricultural practices on soil emissions have been extensively studied, and it is generally acknowledged that $\mathrm{N}$ fertilizer management can have a major impact on these soil $\mathrm{N}_{2} \mathrm{O}$ emissions. As recently reviewed by Snyder et al. (2009), fertilizer amount, type, placement, and timing are all factors influencing emissions. Thus, fertilizer management strategies designed to tighten the synchrony between plant $\mathrm{N}$ requirement and $\mathrm{N}$ availability have the potential to reduce $\mathrm{N}_{2} \mathrm{O}$ emissions.

Enhanced efficiency fertilizers (controlled release fertilizers and fertilizers with nitrification or urease inhibitors) have been investigated with regard to their potential to reduce $\mathrm{N}_{2} \mathrm{O}$ emissions. A recent meta-analysis of the effects of nitrification inhibitors and slow-release $\mathrm{N}$ fertilizers on soil $\mathrm{N}_{2} \mathrm{O}$ emissions concluded that both nitrification inhibitors and polymer-coated slow-release fertilizers significantly reduced $\mathrm{N}_{2} \mathrm{O}$ emissions (Akiyama et al., 2010); however, because some of the studies included in this analysis did not span the growing season, and because cropping systems effects (i.e., grasslands/pasture vs. row crops) were not considered, it is difficult to judge the generality of these conclusions. Indeed, the literature is mixed regarding the effects of enhanced fertilizers on $\mathrm{N}_{2} \mathrm{O}$ emissions.

USDA-ARS National Lab. for Agriculture and the Environment, 2110 Univ. Blvd., Ames, Iowa 50011. Contribution from the USDA-ARS. Trade names and company names are included for the benefit of the reader and do not imply any endorsement or preferential treatment of the product by the authors or the USDA-ARS. The USDA is an equal opportunity provider and employer. Received 30 Apr. 2013. *Corresponding author (tim.parkin@ars.usda.gov).

Published in Agron. J. 105:1-9 (2013)

doi:10.2134/agronj2013.0219

Copyright (c) 2013 by the American Society of Agronomy, 5585 Guilford Road, Madison, WI 53711. All rights reserved. No part of this periodical may be reproduced or transmitted in any form or by any means, electronic or mechanical, including photocopying, recording, or any information storage and retrieval system, without permission in writing from the publisher.
In irrigated corn studies in Colorado, reduced $\mathrm{N}_{2} \mathrm{O}$ emissions have been reported from fertilizers with nitrification inhibitors and polymer-coated urea (Halvorson et al., 2010a, 2010b, 2011; Halvorson and Del Grosso, 2012). Jumadi et al. (2008) compared a split application of urea with a single application of urea plus the nitrification inhibitor dicyandiamide (DCD) and observed higher seasonal $\mathrm{N}_{2} \mathrm{O}$ emissions from corn fertilized with urea $\left(1.87 \mathrm{~kg} \mathrm{~N} \mathrm{ha}^{-1}\right)$ than from urea + DCD $\left(1.06 \mathrm{~kg} \mathrm{~N} \mathrm{ha}^{-1}\right)$. Interestingly, these investigators observed higher soil $\mathrm{NO}_{3}$ concentrations in the urea treatment 4 and $20 \mathrm{~d}$ following fertilization but no significant differences in soil $\mathrm{NO}_{3}$ 12,28 , and $36 \mathrm{~d}$ following fertilization. However, in a rain-fed corn system in Minnesota, Venterea et al. (2011) observed no reductions in $\mathrm{N}_{2} \mathrm{O}$ emissions from polymer-coated urea or urea impregnated with nitrification and urease inhibitors compared with conventional urea. Sistani et al. (2011) measured $\mathrm{N}_{2} \mathrm{O}$ emissions from corn fertilized with a polymer-coated urea (ESN), urea with urease and nitrification inhibitors (SuperU), conventional urea, UAN, and UAN with urease and nitrification inhibitors (UAN+Ag). In 1 yr of their 2-yr study, these investigators found that cumulative $\mathrm{N}_{2} \mathrm{O}$ emissions were generally not significantly different among fertilizer types, and in the other year, the enhanced efficiency fertilizer, ESN, supported higher $\mathrm{N}_{2} \mathrm{O}$ emissions.

Despite the numerous studies on $\mathrm{N}_{2} \mathrm{O}$ production from enhanced fertilizers, due to the variability in factors influencing $\mathrm{N}_{2} \mathrm{O}$ emissions, including soil, weather, and agricultural management (i.e., tillage, fertilizer placement and timing), relatively few generalizations can be generated. The objective of this study was to compare $\mathrm{N}_{2} \mathrm{O}$ emissions from corn fertilized with different EEFs in a central Iowa corn production system.

Abbreviations: DCD, dicyandiamide; DOY, Day of the Year; EEF, enhanced efficiency fertilizer; PVC, polyvinyl chloride; TMN, total mineral nitrogen; UAN, urea-ammonium nitrate. 


\section{MATERIALS AND METHODS}

These experiments were conducted from 2009 through 2011 at field sites located on an Iowa State University research farm located in Boone County, Iowa $\left(42.05^{\circ} \mathrm{N}, 93.71^{\circ} \mathrm{W}\right)$. The two predominant soils at the site are: Canisteo (a fine-loamy, mixed, superactive, calcareous, mesic Typic Endoaquoll) and Nicollet (a fine-loamy, mixed, superactive, mesic Aquic Hapludoll) (Andrews and Diderikson, 1981). From 2008 through 2010, the experimental site was in continuous corn. In 2011, the experimental plots were moved to an adjacent field that had been planted to soybean [Glycine max (L.) Merr.] in 2010. In the fall of 2008, 2009, and 2010, $\mathrm{P}_{2} \mathrm{O}_{5}\left(84 \mathrm{~kg} \mathrm{ha}^{-1}\right)$ and $\mathrm{K}_{2} \mathrm{O}\left(56 \mathrm{~kg} \mathrm{ha}^{-1}\right)$ were applied after harvest and incorporated using strip tillage. The widths of the strip-tilled areas were 18 $\mathrm{cm}$. The corn hybrid Dekalb DKC61-22 RR2 was planted at 79,000 plants $\mathrm{h}^{-1}$ into the strip-tilled areas the following spring of each year. Planting dates were 7 May in 2009 (Day of the Year [DOY] 127), 6 May (DOY 126) in 2010, and 10 May in 2011 (DOY 130). Additional information on the agronomic management of these experiments is provided by Hatfield and Parkin (2013).

Experimental plots for testing the effects of fertilizer type on $\mathrm{N}_{2} \mathrm{O}$ emissions were established immediately after corn planting. The $\mathrm{N}_{2} \mathrm{O}$ emissions plots were located within a 15 - by $45-\mathrm{m}$ area of the field to reduce spatial variations created by differences in soil type. Six replicate plots ( 2 by $2 \mathrm{~m}$ ) of each treatment were established in a completely randomized design. Plots were separated from each other by a 1-m buffer zone. In 2009 and 2010, five treatments were established: (i) a check that received no fertilizer, (ii) a polymer-coated urea (ESN), (iii) urea with urease and nitrification inhibitors (SuperU), (iv) UAN, and (v) UAN with urease and nitrification inhibitors (UAN+Ag). In 2011, two additional fertilizer treatments were included: (i) urea and (ii) Nutrisphere. The same plot sites were used in 2009 and 2010, but new plots were established in 2011.

In all years, the $\mathrm{N}$ fertilizer treatments were added at a rate of $168 \mathrm{~kg} \mathrm{~N} \mathrm{ha}^{-1}$ within $1 \mathrm{wk}$ of corn planting. The solid fertilizers (urea, ESN, SuperU, and Nutrisphere) were surface broadcast (not incorporated), and the UAN and UAN+Ag were sprayed on the surface. Fertilizer was applied to the soil area contained by the polyvinyl chloride (PVC) trace gas anchors by hand at a rate of $168 \mathrm{~kg} \mathrm{~N} \mathrm{ha}^{-1}$. The remaining area inside each plot was fertilized at the same rate (also by hand).

\section{Nitrous Oxide Emissions Measurements}

Nitrous oxide emissions measurements were performed with a non-steady-state, vented, closed chamber method (Parkin and Venterea, 2010). Within each plot, a PVC ring was installed in the corn row. The PVC rings (30-cm diameter by $10 \mathrm{~cm}$ tall) were inserted to a depth of 6 to $8 \mathrm{~cm}$ and served as anchors for the chambers during $\mathrm{N}_{2} \mathrm{O}$ flux measurements. Measurements were performed weekly during the growing season (May-September) in 2009 and 2011, and twice per week during the growing season in 2010 (Parkin, 2008). Flux measurements were performed by placing vented chambers $(30-\mathrm{cm}$ diameter by $10 \mathrm{~cm}$ tall) on the anchors and collecting gas samples 0,15 , 30 , and $45 \mathrm{~min}$ following chamber deployment. The chambers were constructed from PVC and covered with reflective tape. At each time point, chamber headspace gas samples $(11 \mathrm{~mL})$ were collected with polypropylene syringes and immediately injected into evacuated glass vials $(6 \mathrm{~mL})$ fit with butyl rubber stoppers. Nitrous oxide concentrations in the samples were determined with a gas chromatography instrument (Model GC17A, Shimadzu) equipped with a ${ }^{63} \mathrm{Ni}$ electron capture detector and a stainless steel column $(0.3175-\mathrm{cm}$ diameter by $74.54 \mathrm{~cm}$ long $)$ with PorapakQ (80-100 mesh), and $\mathrm{Ar} / \mathrm{CH}_{4}(95 / 5)$ as the carrier gas. Samples were introduced into the gas chromatograph using an autosampler described by Arnold et al. (2001). Nitrous oxide fluxes were computed from the change in $\mathrm{N}_{2} \mathrm{O}$ concentration with time by linear regression or with a modification of the algorithm developed by Hutchinson and Mosier (1981), as described by Parkin et al. (2012). Based on our precision of $\mathrm{N}_{2} \mathrm{O}$ measurement of $4.4 \%$, our estimated minimum detectable flux ranged from 1.3 to $5.3 \mathrm{~g} \mathrm{~N}_{2} \mathrm{O}-\mathrm{N} \mathrm{ha}^{-1} \mathrm{~d}^{-1}$ (Parkin et al., 2012).

At the time of each flux measurement, the soil water content $(0-6 \mathrm{~cm})$ was measured with a soil moisture probe (Delta-T Theta Probes, Dynamax). The soil temperature $(5 \mathrm{~cm})$ was measured at the time of gas sampling using a digital soil thermocouple temperature probe. Measurements of precipitation and air temperature were made at hourly intervals at a weather station located at the research farm (approximately $200 \mathrm{~m}$ away from the study site). The anchors were left in place during the sampling period in each year but moved from year to year.

\section{Fertilizer Release Rates}

In 2011, temporal variations in soil $\mathrm{NO}_{3}$ and $\mathrm{NH}_{4}$ were monitored following application of urea, SuperU, Nutrisphere, and ESN. To accomplish this, we installed $160 \mathrm{PVC}$ tubes $(14.5 \mathrm{~cm}$ long by $5.2-\mathrm{cm}$ i.d.) to a depth of $10 \mathrm{~cm}$ approximately $15 \mathrm{~cm}$ away from a corn row directly adjacent to the plots where $\mathrm{N}_{2} \mathrm{O}$ emissions were measured. A measured amount of fertilizer (corresponding to a rate of $168 \mathrm{~kg} \mathrm{~N} \mathrm{ha}^{-1}$ ) was added to each tube (from two to four fertilizer prills). Thirty-two PVC tubes, each with one of the fertilizers identified above, were randomly established, plus 32 tubes with no added fertilizer. The tubes were covered with loose-fitting aluminum caps to prevent rainfall-induced $\mathrm{N}$ leaching from the soil within the tubes. The closed-top, solid cylinder is a recommended method for estimating in situ net $\mathrm{N}$ mineralization (Hart et al., 1994; Robertson et al., 1999). We adopted this method because measurement of the net release of $\mathrm{NO}_{3}+\mathrm{NO}_{2}$ and $\mathrm{NH}_{4}$ from soil organic matter (i.e., net $\mathrm{N}$ mineralization) is analogous to measuring the net release of $\mathrm{NO}_{3}+\mathrm{NO}_{2}$ and $\mathrm{NH}_{4}$ from fertilizer prills. At eight times (at approximate 10-d intervals) throughout the growth season, four replicate tubes of each fertilizer treatment + four check tubes were removed from the field. After the tubes were collected from the field, any identifiable fertilizer prills within the tubes were removed. The tubes were then placed in plastic bags, returned to the laboratory, and frozen until $\mathrm{NO}_{3}$ and $\mathrm{NH}_{4}$ analyses could be performed. Nitrate and $\mathrm{NH}_{4}$ analyses were performed by thawing the soil in the tubes, sieving the soil ( $0.5-\mathrm{cm}$ mesh), and extracting $100 \mathrm{~g}$ of soil with $0.4 \mathrm{~L}$ of 2 mol L ${ }^{-1} \mathrm{KCl}$ by shaking for $1 \mathrm{~h}$. The $\mathrm{KCl}$ extracts were filtered and $\mathrm{NO}_{3}\left(+\mathrm{NO}_{2}\right)$ and $\mathrm{NH}_{4}$ were determined by colorimetric analyses on a Lachat autoanalyzer following the procedure described by Keeney and Nelson (1982). Subsamples of soils within the tubes were analyzed for water content determination by oven drying at $105^{\circ} \mathrm{C}$. Nitrate $\left(+\mathrm{NO}_{2}\right)$ and $\mathrm{NH}_{4}$ values are expressed on a drysoil basis. 


\section{Soil Sampling and Analyses}

Surface soil $(0-15-\mathrm{cm})$ samples were collected in May 2009 at Site 1 and April 2011 at Site 2. Four soil cores (3.35-cm diameter) were collected from each site and bulked. In the laboratory, samples were weighed and sieved $(5 \mathrm{~mm})$. Subsamples were collected for water content determination by oven drying at $105^{\circ} \mathrm{C}$, and the remaining soil was air dried. Air-dried samples were ground with a roller mill for organic $\mathrm{C}$ and $\mathrm{N}$ determination by dry combustion with a Carlo-Erba NA1500CHN elemental analyzer (Haake Buchler Instruments) after removal of carbonates (Nelson and Sommers, 1996). Soil $\mathrm{pH}$ was measured in 1:1 distilled water/soil slurries. Bulk density was computed from the soil sample weights (corrected for water content) and the known core volume. Soil texture analyses were performed by Midwest Laboratories, Inc., Omaha, NE. Physical and chemical properties of the soils from the two sites are shown in Table 1.

\section{Statistical Analyses}

Autocorrelation analysis of $\mathrm{N}_{2} \mathrm{O}$ fluxes measured in individual plots with time were performed with Statistix software (Analytical Software) using the method of Box and Jenkins (1976). These analyses showed no significant autocorrelation, therefore no attempt was made to combine the analysis of dates within a year using a mixed model ANOVA with dates as repeated measures to statistically examine the response with time. Instead, cumulative $\mathrm{N}_{2} \mathrm{O}$ emissions for each plot were calculated by linear interpolation and numerical integration of the measured daily fluxes. The cumulative $\mathrm{N}_{2} \mathrm{O}$ fluxes were averaged across replicate plots and analyzed, which is one of the approaches suggested by Mead (1988). Cumulative $\mathrm{N}_{2} \mathrm{O}$ losses for each year were independently analyzed by one-way ANOVA. When an overall $F$ test was significant, individual treatment effects were assessed by the Bonferroni $t$-test method (SigmaStat, Exeter Software Co.). Sample date was not included in the ANOVA model. Analyses of the soil $\mathrm{NO}_{3}$ and $\mathrm{NH}_{4}$ concentrations at each sampling time in the fertilizer $\mathrm{N}$ release experiment were conducted by one-way ANOVA, and individual treatment effects were assessed by Fisher's LSD.

\section{RESULTS}

\section{Nitrous Oxide Emissions}

Nitrous oxide emissions measurements were initiated in 2009 immediately following fertilizer application on 5 May (DOY 125). The several small $(<10-\mathrm{mm})$ precipitation events (Fig. 1A) that occurred during the 18-d period following fertilizer application did not influence $\mathrm{N}_{2} \mathrm{O}$ emissions (Fig. 1B). On 26 May (DOY 146), however, a 70-mm rainfall event occurred and on 27 May (DOY 147) $\mathrm{N}_{2} \mathrm{O}$ emissions in the ESN, SuperU, and UAN+Ag treatments increased approximately 10-fold from their pre-rainfall rates (20 May, DOY 140). The UAN treatment increased to $191 \mathrm{~g} \mathrm{~N}_{2} \mathrm{O}-\mathrm{N} \mathrm{ha}^{-1} \mathrm{~d}^{-1}$ (from $49 \mathrm{~g}$ $\mathrm{N}_{2} \mathrm{O}-\mathrm{N} \mathrm{ha}^{-1} \mathrm{~d}^{-1}$ ) and the check treatment increased twofold $\left(31 \mathrm{~g} \mathrm{~N}_{2} \mathrm{O}-\mathrm{N} \mathrm{ha}^{-1} \mathrm{~d}^{-1}\right.$ on DOY 140 to $65 \mathrm{~g} \mathrm{~N}_{2} \mathrm{O}-\mathrm{N} \mathrm{ha}^{-1} \mathrm{~d}^{-1}$ on DOY 147). Volumetric soil water content increased from $0.3 \mathrm{~m}^{3} \mathrm{~m}^{-3}$ on DOY 140 to $0.4 \mathrm{~m}^{3} \mathrm{~m}^{-3}$ on 23 June (DOY 174)

(Fig. 1A). Another smaller peak $\mathrm{N}_{2} \mathrm{O}$ emission occurred on DOY 174 in response to precipitation events that occurred on 18 June (DOY 169, $38 \mathrm{~mm}$ ), DOY 170 (8 mm), and DOY 172 $(21 \mathrm{~mm})$, with the ESN treatment exhibiting the largest flux
Table I. Properties of soil samples collected at two sites $(0-15 \mathrm{~cm})$. Analyses were performed on three cores $(0-15 \mathrm{~cm})$ collected from each location.

\begin{tabular}{lcc}
\multicolumn{1}{c}{ Soil property } & $\begin{array}{c}\text { Site I } \\
\text { 2009-20 I 0 }\end{array}$ & $\begin{array}{c}\text { Site 2 } \\
\text { 20 I I }\end{array}$ \\
\hline $\mathrm{pH}$ & 6.7 & 7.2 \\
Organic N, g kg-1 & 2.88 & 2.69 \\
Organic C, g kg-1 & 32.8 & 32.9 \\
Sand, g kg-1 & 455 & 420 \\
Silt, g kg-1 & 340 & 380 \\
Clay, g kg-1 & 205 & 200 \\
Bulk density, $\mathrm{Mg} \mathrm{m}^{-3}$ & 1.35 & 1.15 \\
\hline
\end{tabular}

$\left(148 \mathrm{~g} \mathrm{~N}_{2} \mathrm{O}-\mathrm{N} \mathrm{ha}^{-1} \mathrm{~d}^{-1}\right)$. Throughout the rest of the season, fluxes generally remained low $\left(<30 \mathrm{~g} \mathrm{~N}_{2} \mathrm{O}-\mathrm{N} \mathrm{ha}^{-1} \mathrm{~d}^{-1}\right)$.

The first $21 \mathrm{~d}$ following fertilizer application in 2010 were characterized by low rainfall ( $<22 \mathrm{~mm}$ cumulative precipitation) (Fig. 2A). During the next 24-d period (4-27 June, DOY 155-178), however, the site received a total of $232 \mathrm{~mm}$ of rain. During this time period, several $\mathrm{N}_{2} \mathrm{O}$ emissions peaks were observed in the fertilizer treatments but not the check plots (Fig. 2B). Several smaller peak $\mathrm{N}_{2} \mathrm{O}$ events were observed between 29 June (DOY 180) and DOY 210.

Cumulative precipitation during the 2011 growing season $(390 \mathrm{~mm})$ was less than observed in $2010(700 \mathrm{~mm})$ and 2009 (491 mm) (Fig. 3). The 30-yr average growing season precipitation for the region is $521.6 \mathrm{~mm}$. During the 2011 sampling season, there were only four rainfall events that exceeded 25 $\mathrm{mm}$. The first of these events occurred on 20-21 May (DOY $140-141$ ) when a total of $42 \mathrm{~mm}$ of precipitation was recorded. This event triggered a small peak in $\mathrm{N}_{2} \mathrm{O}$ emissions on DOY 144. A 44.5-mm rainfall that occurred on 9 June (DOY 160) did not result in stimulated $\mathrm{N}_{2} \mathrm{O}$ emissions. Nitrous oxide emissions were not sampled until 13 June (DOY 164) so it is possible that any peak emission might have been missed; however, the period of DOY 160 through DOY 164 also experienced a temperature decline, with daily air temperatures averaging $16.3^{\circ} \mathrm{C}$ compared with a mean daily air temperature of $27.8^{\circ} \mathrm{C}$ during the previous $4 \mathrm{~d}$. The 22.6-mm rainfall event that occurred on 10 to 11 July (DOY 191-192) resulted in an increase in soil water content from $0.186 \mathrm{~m}^{3} \mathrm{~m}^{-3}$ on DOY 186 to $0.269 \mathrm{~m}^{3} \mathrm{~m}^{-3}$ on DOY 192. The largest $\mathrm{N}_{2} \mathrm{O}$ emission peaks in the 2011 season were observed on DOY 192, with even the check plots exhibiting an increase from the previous week.

Plots of cumulative $\mathrm{N}_{2} \mathrm{O}$ loss show the relative temporal dynamics associated with each fertilizer treatment (Fig. 4). In 2009, a breakpoint occurred $20 \mathrm{~d}$ following fertilizer application at 27 May (DOY 147) (Fig. 4A). At this point, there was no significant difference between the fertilizer treatments and the check. On 3 June (DOY 154), separation between the treatments increased, with the ESN and SuperU treatments being significantly $(P<0.05)$ greater than the check, UAN, and UAN + Ag treatments. By the end of the sampling period (5 October, DOY 278) cumulative $\mathrm{N}_{2} \mathrm{O}$ losses from all the fertilizer treatments were significantly greater than the check (Table 2).

The patterns of cumulative $\mathrm{N}_{2} \mathrm{O}$ losses in 2010 (Fig. 4B) were different from those observed in 2009. In 2010, a breakpoint in the increase in cumulative $\mathrm{N}_{2} \mathrm{O}$ emissions occurred at DOY 165 , $28 \mathrm{~d}$ after fertilizer application. At this point, $\mathrm{N}_{2} \mathrm{O}$ emissions from the fertilizer treatments began to diverge from those of the 


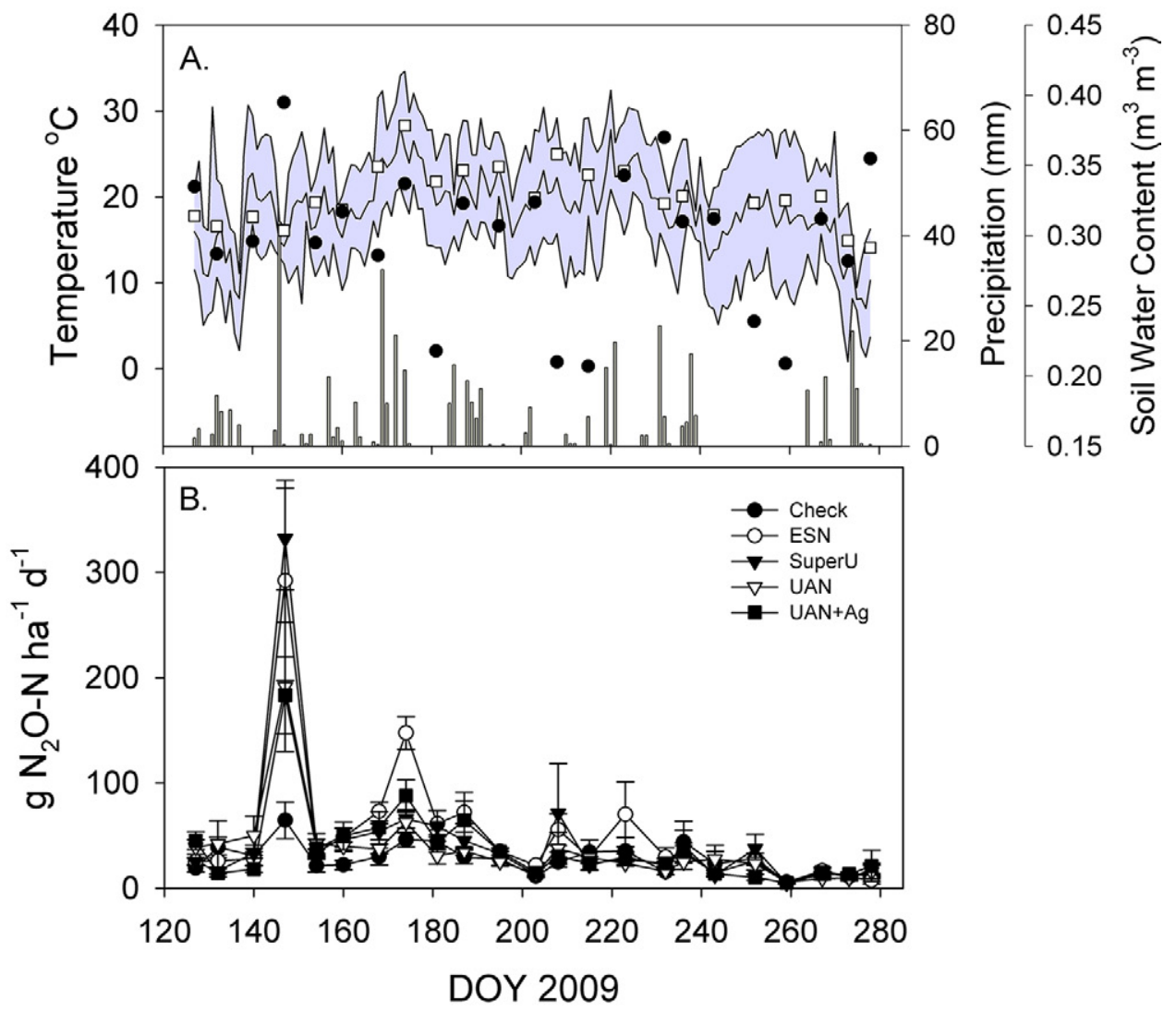

Fig. I. (A) Weather and soil conditions and (B) mean daily $\mathrm{N}_{2} \mathrm{O}$ emissions and standard errors for 2009. In (A), daily maximum and minimum air temperatures bound the shaded area, daily precipitation is shown as vertical bars, 5 -cm soil temperature are open squares, and volumetric soil water contents $(0-6 \mathrm{~cm})$ are solid circles; in (B), UAN is urea- $\mathrm{NH}_{4} \mathrm{NO}_{3}$ and UAN+Ag is UAN with Agrotain Plus.

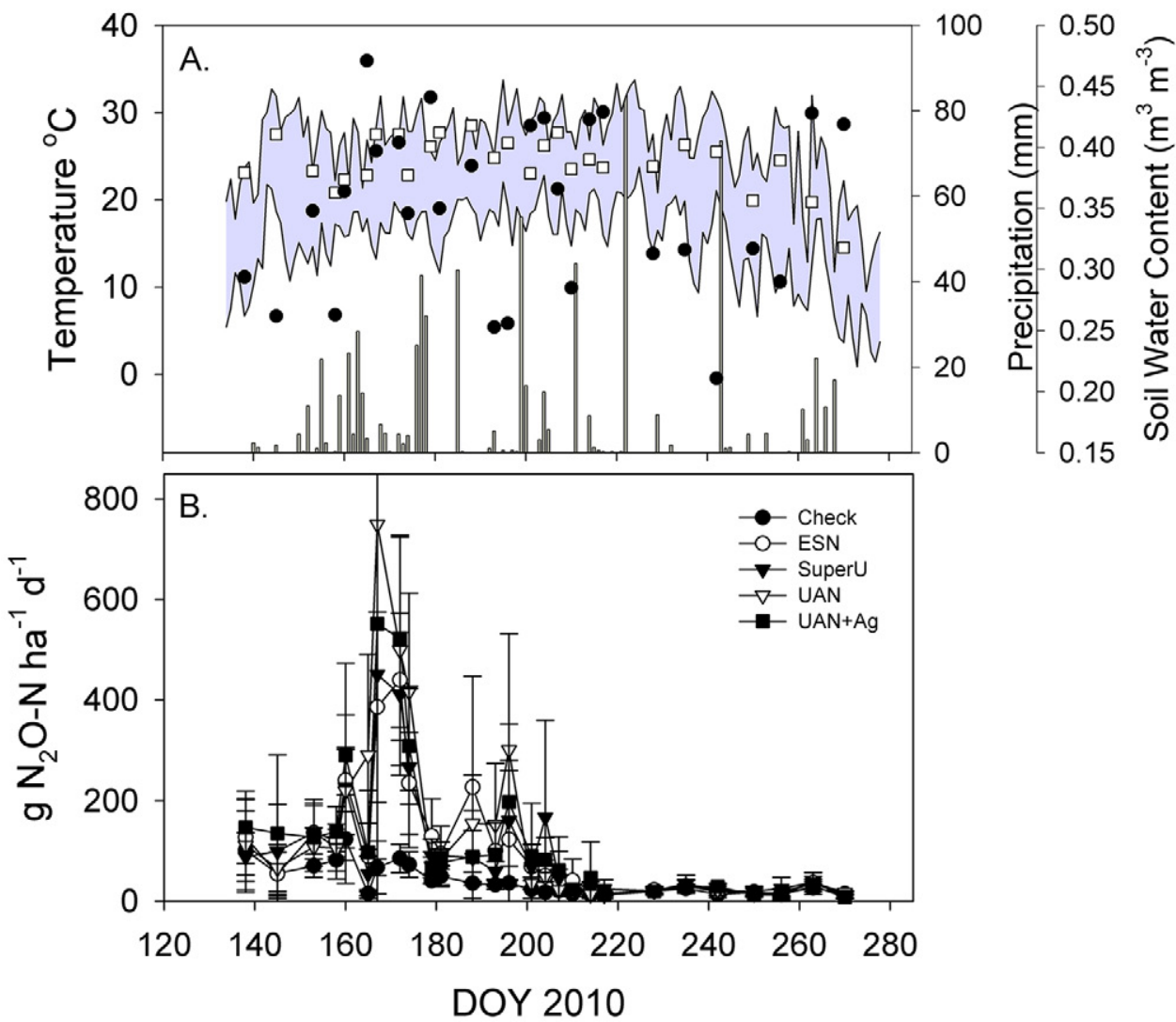

Fig. 2. (A) Weather and soil conditions and (B) mean daily $\mathrm{N}_{2} \mathrm{O}$ emissions and standard errors for 20 I0. In (A), daily maximum and minimum air temperatures bound the shaded area, daily precipitation is shown as vertical bars, 5 -cm soil temperature are open squares, and volumetric soil water contents $(0-6 \mathrm{~cm})$ are solid circles; in (B), UAN is urea- $\mathrm{NH}_{4} \mathrm{NO}_{3}$ and UAN+Ag is UAN with Agrotain Plus. 


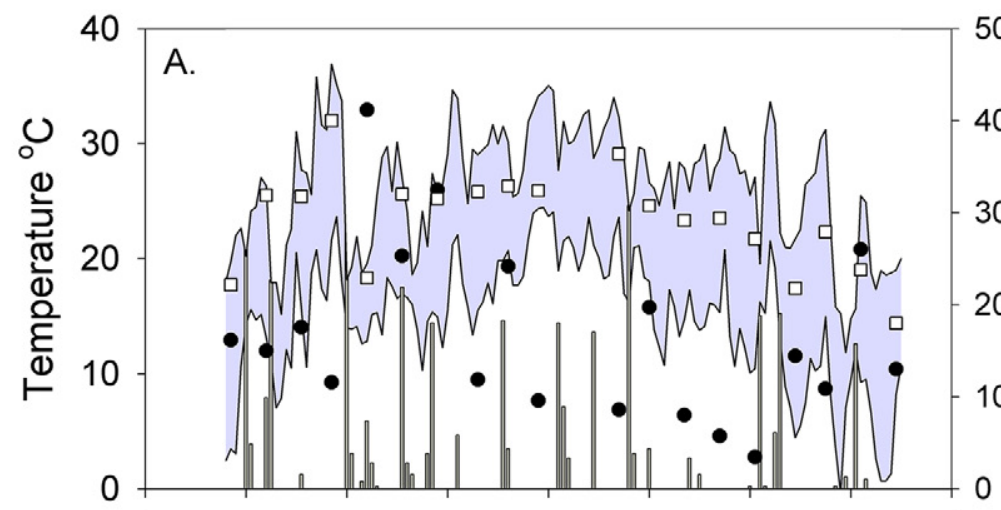

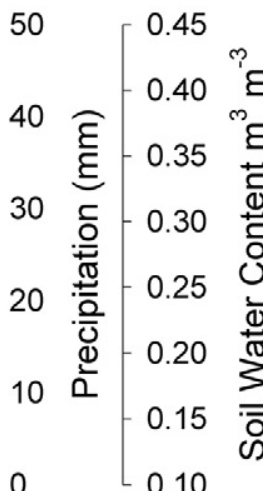

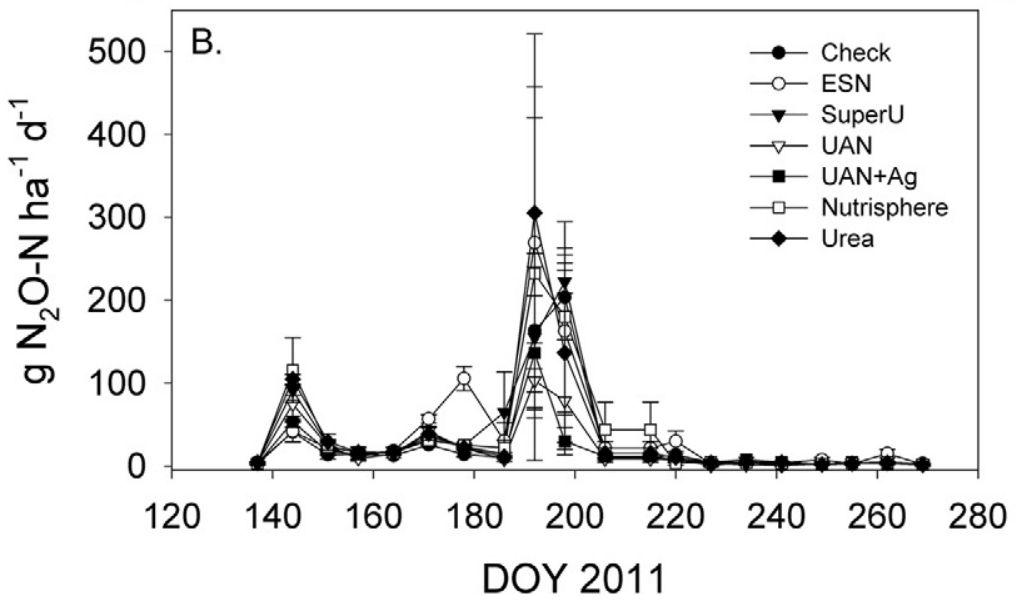

Fig. 3. (A) Weather and soil conditions and (B) mean daily $\mathrm{N}_{2} \mathrm{O}$ emissions and standard errors for $20 \mathrm{II}$. In (A), daily maximum and minimum air temperatures bound the shaded area, daily precipitation is shown as vertical bars, 5 -cm soil temperature are open squares, and volumetric soil water contents $(0-6 \mathrm{~cm})$ are solid circles; in (B), UAN is urea-NH $\mathrm{NO}_{3}$ and UAN+Ag is UAN with Agrotain Plus.

check plots; however, no significant differences were observed $(P=0.113)$. By DOY 174 , cumulative $\mathrm{N}_{2} \mathrm{O}$ losses from all fertilizer treatments were significantly greater than the check. These differences persisted to the end of the sampling period in 2010 (Table 2).

Cumulative $\mathrm{N}_{2} \mathrm{O}$ losses for 2011 are shown in Fig. 4C. Nitrous oxide emissions from the urea and Nutrisphere treatments increased at a greater rate than the other treatments during the $15 \mathrm{~d}$ following fertilizer application, and at DOY 151, cumulative $\mathrm{N}_{2} \mathrm{O}$ loss from these two treatments were significantly $(P<0.027)$ different from all other fertilizer treatments and the check. By DOY 178. further separation between the treatments had occurred. The urea and Nutrisphere treatments remained significantly different from the other treatments, and

Table 2. Growing season $\mathrm{N}_{2} \mathrm{O}$ emissions for the three study years. Mean separation in each year was determined by the Bonferroni t-test procedure.

\begin{tabular}{|c|c|c|c|}
\hline \multirow[b]{2}{*}{ Treatment } & \multicolumn{3}{|c|}{ Cumulative seasonal $\mathrm{N}_{2} \mathrm{O}$ loss } \\
\hline & 2009 & 2010 & 2011 \\
\hline & \multicolumn{2}{|c|}{$\mathrm{kg} \mathrm{N}_{2} \mathrm{O}-\mathrm{N} \mathrm{ha}^{-1}$} & 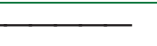 \\
\hline Check & $4.30 \mathrm{a}(1.01) \dagger$ & 5.00 a $(1.04)$ & I. 17 a $(0.44)$ \\
\hline ESN & 7.94 c (2.17) & $12.1 \mathrm{~b}(2.00)$ & $2.88 \mathrm{~b}(0.60)$ \\
\hline SuperU & $7.03 \mathrm{bc}(1.15)$ & I I.8 b (2.84) & $2.92 \mathrm{~b}(\mathrm{I} .28)$ \\
\hline Urea- $\mathrm{NH}_{4} \mathrm{NO}_{3}$ (UAN) & $5.55 \mathrm{ab}(1.20)$ & $12.5 \mathrm{~b}(2.98)$ & $2.16 \mathrm{~b}(1.13)$ \\
\hline UAN + Agrotain Plus & $5.70 \mathrm{ab}(1.30)$ & I3.4 b (4.7I) & $2.36 \mathrm{~b}(0.43)$ \\
\hline Nutrisphere & - & - & $2.59 \mathrm{~b}(0.18)$ \\
\hline Urea & - & - & $2.88 \mathrm{~b}(\mathrm{I} .32)$ \\
\hline
\end{tabular}

$\dagger$ Means with standard deviations in parentheses. Means followed by different letters in the same column are significantly different $(P \leq 0.05)$. the SuperU treatment significantly different from the check $(P \leq 0.05)$. At DOY 171 , cumulative $\mathrm{N}_{2} \mathrm{O}$ emissions from the ESN treatment started to increase and by DOY 206 reached levels observed in the urea treatment. By the end of the sampling period in 2011, cumulative $\mathrm{N}_{2} \mathrm{O}$ emissions from all of the fertilizer treatments were significantly greater than the check $(P \leq 0.05)$, but there were no differences between fertilizer types (Table 2).

\section{Nitrogen Release from Fertilizer Prills}

Differences in the temporal dynamics of $\mathrm{N}_{2} \mathrm{O}$ emissions among the different fertilizers may be partially related to $\mathrm{NO}_{3}$ and $\mathrm{NH}_{4}$ availability. In 2011, temporal changes in soil inorganic $\mathrm{N}$ (top $10 \mathrm{~cm}$ ) were measured following the addition of solid fertilizers (Fig. 5). During the first $37 \mathrm{~d}$ following fertilizer applications (Fig. 5), soil $\mathrm{NO}_{3}-\mathrm{N}$ accumulation in the ESN treatment $\left(0.50 \mathrm{~kg} \mathrm{~N} \mathrm{ha}^{-1} \mathrm{~d}^{-1}\right)$ was significantly slower than in the SuperU $\left(1.61 \mathrm{~kg} \mathrm{~N} \mathrm{ha}^{-1} \mathrm{~d}^{-1}\right)$ and urea $\left(1.26 \mathrm{~kg} \mathrm{~N} \mathrm{ha}^{-1} \mathrm{~d}^{-1}\right)$ treatments but not different than the check treatment $\left(0.33 \mathrm{~kg} \mathrm{~N} \mathrm{ha}^{-1} \mathrm{~d}^{-1}\right)$. Due to high variability in $\mathrm{NO}_{3}$ concentrations, the rate of $\mathrm{NO}_{3}-\mathrm{N}$ accumulation in the Nutrisphere treatment $\left(0.82 \mathrm{~kg} \mathrm{~N} \mathrm{ha}^{-1} \mathrm{~d}^{-1}\right)$ was not significantly different from the other treatments. There were no significant differences $(P=$ 0.54 ) in soil $\mathrm{NO}_{3}$ immediately after fertilizer application (DOY 136), and the average soil $\mathrm{NO}_{3}-\mathrm{N}$ level across all treatments was $11.5 \mathrm{~kg} \mathrm{NO}_{3}-\mathrm{Nha}^{-1}$.

At the next sampling time (DOY 146), however, $\mathrm{NO}_{3}-\mathrm{N}$ in the urea treatment $\left(42.8 \mathrm{~kg} \mathrm{~N} \mathrm{ha}^{-1}\right)$ was significantly higher than the ESN, SuperU, and check treatments. Also, $\mathrm{NO}_{3}-\mathrm{N}$ 


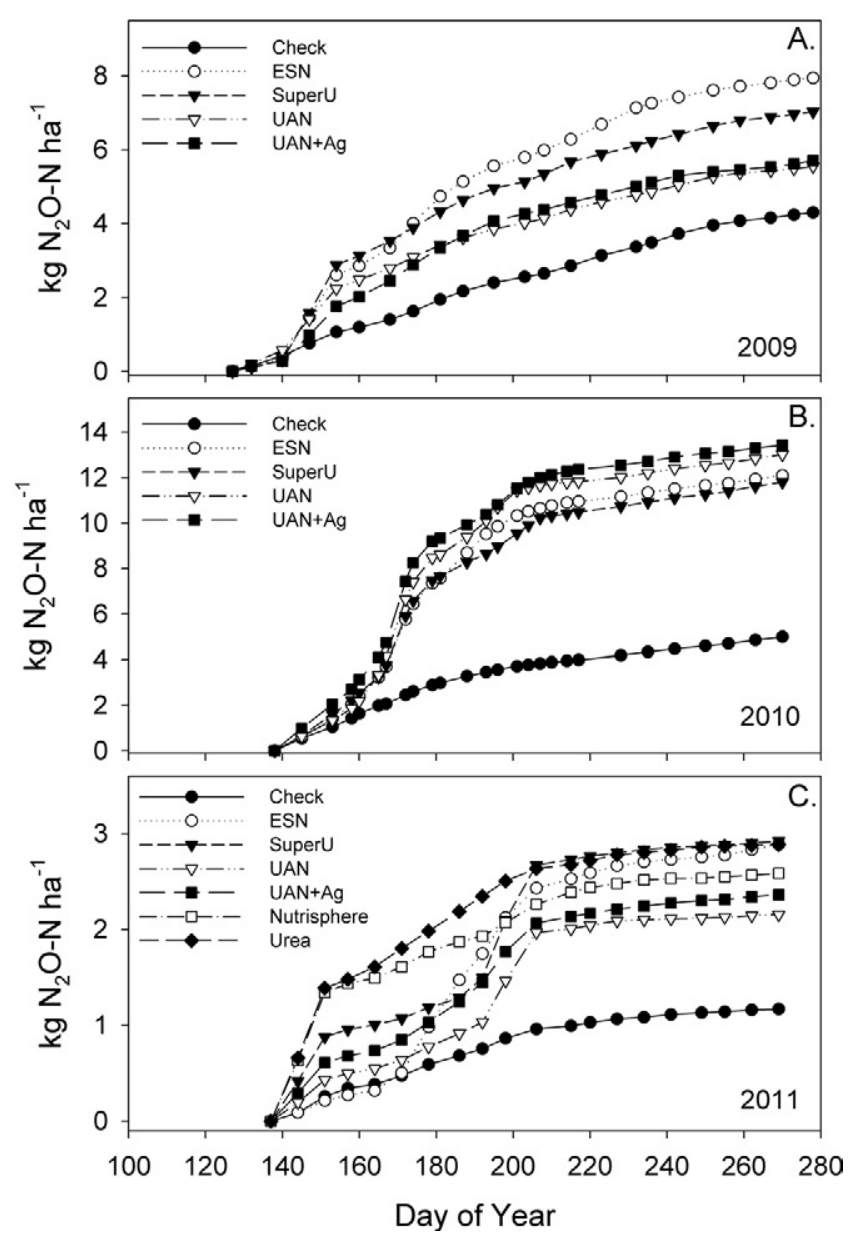

Fig. 4. Cumulative seasonal $\mathrm{N}_{2} \mathrm{O}$ emissions for the treatments in (A) 2009, (B) 20I0, and (C) 20II; UAN is urea- $\mathrm{NH}_{4} \mathrm{NO}_{3}$ and UAN+Ag is UAN with Agrotain Plus.

in the Nutrisphere treatment $\left(34.0 \mathrm{~kg} \mathrm{~N} \mathrm{ha}^{-1}\right)$ was significantly higher $(P<0.05)$ than the check treatment. The higher $\mathrm{NO}_{3}-\mathrm{N}$ levels in the urea and Nutrisphere treatments correspond with the higher cumulative $\mathrm{N}_{2} \mathrm{O}$ loss observed for these treatments on DOY 151 (Fig. 4C). By DOY 180, $\mathrm{NO}_{3}$ had increased in all treatments, and all fertilizer treatments had higher $\mathrm{NO}_{3}-\mathrm{N}$ than the check, but $\mathrm{NO}_{3}$ was not significantly different among the different fertilizers. Soil $\mathrm{NH}_{4}$ concentrations (Fig. 5B) averaged $6.15 \mathrm{~kg} \mathrm{ha}^{-1}$ at time zero and increased significantly by DOY 146 , at which time: (i) the check $\left(5.52 \mathrm{~kg} \mathrm{NH}_{4}-\mathrm{N} \mathrm{ha}^{-1}\right)$ was significantly lower than all the other treatments, (ii) ESN was significantly different from the other fertilizers, and (iii) Nutrisphere, urea, and SuperU were not significantly different $(P>$ $0.93)$ from each other. Total mineral $\mathrm{N}(\mathrm{TMN})$ represents the sum of the $\mathrm{NO}_{3}$ and $\mathrm{NH}_{4}$ pools in the top $10 \mathrm{~cm}$ (Fig. 5C), and changes in soil TMN generally followed the temporal patterns exhibited by $\mathrm{NH}_{4}$. At the end of the incubation period (DOY 229), the mean soil TMN concentrations in the check treatment $\left(18.3 \mathrm{~kg} \mathrm{~N} \mathrm{ha}^{-1}\right)$ were significantly lower $(P<0.05)$ than any of the fertilizer treatments. Among the $\mathrm{N}$ fertilizers, SuperU had the highest $\mathrm{N}$ content $\left(115 \mathrm{~kg} \mathrm{~N} \mathrm{ha}^{-1}\right)$, which was significantly greater than the Nutrisphere treatment $\left(73.3 \mathrm{~kg} \mathrm{~N} \mathrm{ha}^{-1}, P=\right.$ $0.031)$, the urea treatment $\left(79.7 \mathrm{~kg} \mathrm{~N} \mathrm{ha}^{-1}, P=0.062\right)$, and the ESN treatment $\left(83.4 \mathrm{~kg} \mathrm{~N} \mathrm{ha}^{-1}, P=0.091\right)$. Total mineral $\mathrm{N}$
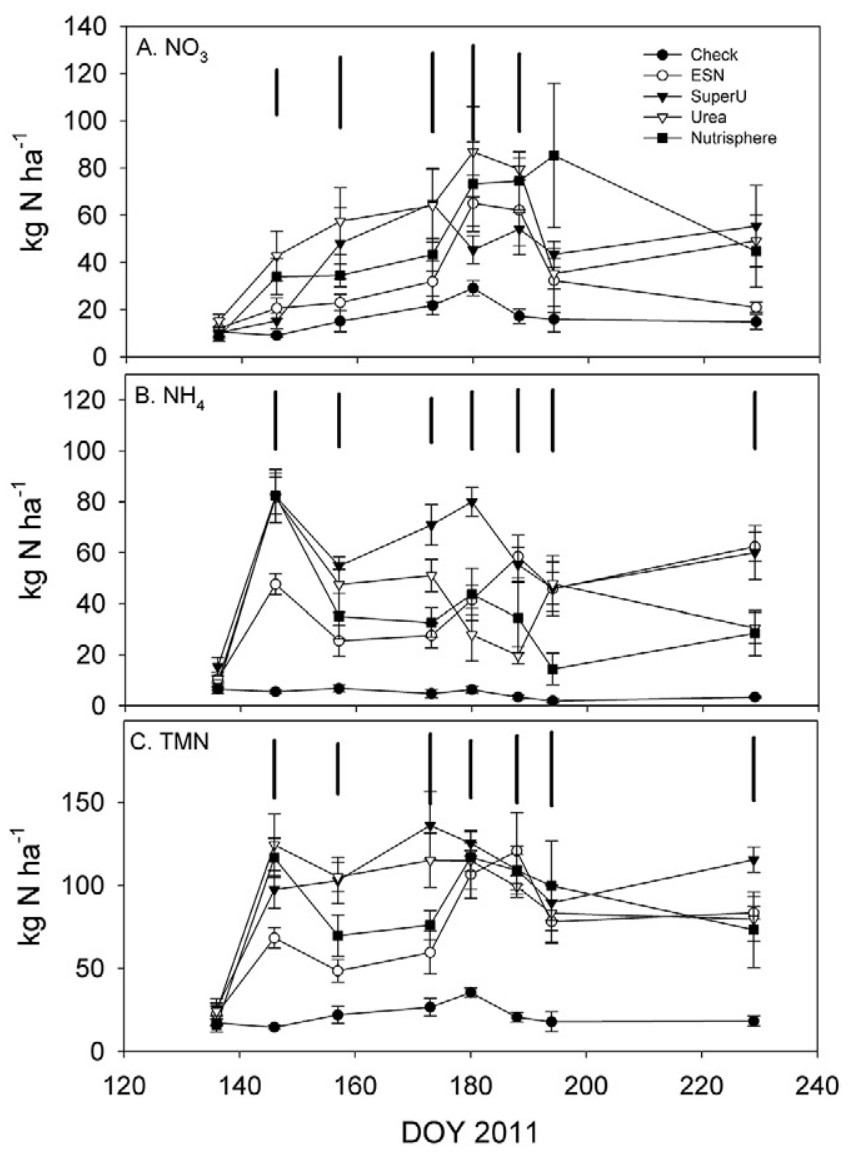

Fig. 5. Temporal dynamics of soil (A) $\mathrm{NO}_{3}$, (B) $\mathrm{NH}_{4}$, and (C) total mineral N (TMN) in tubes installed in the soil and fertilized with solid fertilizer material in $201 \mathrm{I}$. Tubes were installed to a depth of $10 \mathrm{~cm}$ and capped with loose-fitting aluminum caps to prevent rainfall-induced leaching and allow air circulation. Error bars at the top of each panel indicate Fisher's least significant difference.

contents of the Nutrisphere, urea, and ESN treatments were not significantly different from one another $(P>0.574)$.

\section{DISCUSSION}

Nitrous oxide emissions from soil typically show a positive response to fertilizer addition (Bouwman et al., 2002; Halvorson et al., 2008, 2013; Hoben et al., 2011; Malhi et al., 2006; McSwiney and Robertson, 2005; Mosier et al., 2006). The potential for EEFs (slow release and/or inhibitors) for reducing $\mathrm{N}_{2} \mathrm{O}$ emissions is based on the premise that synchronizing $\mathrm{N}$ availability with crop $\mathrm{N}$ demand will result in low soil $\mathrm{NO}_{3}$ concentrations and result in less $\mathrm{N}_{2} \mathrm{O}$ production. In a study on irrigated corn in Colorado, Halvorson and DelGrosso (2012) observed that ESN and SuperU had lower soil $\mathrm{NO}_{3}$ levels than conventional urea during the 2-mo period following fertilizer addition. The dynamics of $\mathrm{N}$ release from $\mathrm{EEFs}$ are not always consistent, however. Jumadi et al. (2008) observed an inconsistent temporal response of soil $\mathrm{NO}_{3}$ concentrations $(0-10 \mathrm{~cm})$ during the $36-\mathrm{d}$ period following the application of urea, a controlled-release fertilizer, and urea plus the nitrification inhibitor DCD. Four days following fertilizer application, soil $\mathrm{NO}_{3}$ concentrations in the urea treatment $\left(37 \mathrm{mg} \mathrm{NO} \mathrm{N} \mathrm{N}_{3}-1\right.$ soil) were significantly higher than the urea + DCD treatment (approximately $20 \mathrm{mg} \mathrm{NO}_{3}-\mathrm{N} \mathrm{kg}^{-1}$ soil). No significant 
differences in soil $\mathrm{NO}_{3}$ concentrations were observed $12 \mathrm{~d}$ after fertilization. Significantly higher $\mathrm{NO}_{3}-\mathrm{N}$ concentrations were again observed $20 \mathrm{~d}$ following fertilization, but not 28 or $36 \mathrm{~d}$ following fertilization. In a study on a fallow soil comparing anhydrous $\mathrm{NH}_{3}$ with and without the nitrification inhibitor nitrapyrin [2-chloro-6-(trichloromethyl) pyridine], Magalhães et al. (1984) observed that the rate of soil $\mathrm{NO}_{3}$ formation was only slightly reduced in the presence of the inhibitor. In two of the soils studied, $\mathrm{NO}_{3}$ concentrations in both the inhibitor and no-inhibitor treatments exceeded $20 \mathrm{mg} \mathrm{NO}_{3}-\mathrm{N} \mathrm{kg}^{-1}$ soil after $14 \mathrm{~d}$. In contrast to the Halvorson and DelGrosso (2012) results, the data of Venterea et al. (2011) showed higher growing season (June-September) $\mathrm{NO}_{3}$ concentrations $(0-15 \mathrm{~cm})$ in soils fertilized with SuperU and ESN than conventional urea. These investigators observed that peak soil $\mathrm{NO}_{3}$ concentrations occurred in the month of July in both study years. In a dry year (2008), peak soil $\mathrm{NO}_{3}$ concentrations in the conventional tillage treatment were approximately 60,40 , and $25 \mathrm{mg} \mathrm{NO}_{3}-\mathrm{N} \mathrm{kg}^{-1}$ soil in the SuperU, ESN, and conventional urea treatments, respectively. In 2009, peak soil $\mathrm{NO}_{3}$ concentrations were approximately 45, 25 , and $15 \mathrm{mg} \mathrm{NO}_{3}-\mathrm{N} \mathrm{kg}^{-1}$ soil in the SuperU, ESN, and conventional urea treatments, respectively (Venterea et al., 2011). The results of our study indicate that in 2011 , release of soil $\mathrm{NO}_{3}$ from ESN was delayed relative to urea and SuperU from the date of fertilizer application until 22 June, but by 29 June $\mathrm{NO}_{3}$ concentrations in the fertilized plots exceeded $35 \mathrm{mg} \mathrm{NO}_{3}-\mathrm{N} \mathrm{kg}^{-1}$ soil. Thus, in some cases, EEFs have been shown to be effective in reducing soil $\mathrm{NO}_{3}$ concentrations relative to conventional fertilizers, but what level of reduction is necessary to impact soil $\mathrm{N}_{2} \mathrm{O}$ production from denitrification?

The question, "Do lower soil $\mathrm{NO}_{3}$ concentrations necessarily result in lower $\mathrm{N}_{2} \mathrm{O}$ emissions?" may be partially addressed by considering the kinetics of denitrification. Denitrification has been reported to follow Michaelis-Menton kinetics (Firestone et al., 1979; Betlach and Tiedje, 1981; Murray et al., 1989), thus below a given $\mathrm{NO}_{3}$ concentration threshold, increases in $\mathrm{NO}_{3}$ will result in increased denitrification, up to $V_{\max }$. Kinetic analyses of denitrification indicate that the half-saturation constant of denitrification with respect to $\mathrm{NO}_{3}\left(K_{\mathrm{m}, \mathrm{NO} 3}\right)$ in soil and soil slurries can range from $1.3 \mathrm{mmol} \mathrm{L}^{-1}$ to $90 \mu \mathrm{mol} \mathrm{L}^{-1} \mathrm{NO}_{3}$ (Maag et al., 1997) and 1.7 to $13.7 \mu \mathrm{mol} \mathrm{L}^{-1}$ for denitrifying cultures (Christensen and Tiedje, 1988; Betlach and Tiedje, 1981; Murray et al., 1989). In theory, under non-limiting $C$ conditions, if $\mathrm{NO}_{3}$ concentrations are twice the $K_{\mathrm{m}}$, denitrification will be zero order with respect to $\mathrm{NO}_{3}$. Thus, a soil with a $\mathrm{NO}_{3}$ concentration of $1 \mathrm{mg} \mathrm{NO}_{3}-\mathrm{N} \mathrm{kg}^{-1}$ soil, a bulk density of $1.2 \mathrm{~g} \mathrm{~cm}^{-3}$, and a volumetric soil water content of $25 \%$ would have a soil solution $\mathrm{NO}_{3}$ concentration of $342 \mu \mathrm{mol} \mathrm{NO} \mathrm{L}^{-1}$ soil water (assuming all the $\mathrm{NO}_{3}$ was dissolved in the soil aqueous phase). If the $K_{\mathrm{m}, \mathrm{NO} 3}$ of this soil was $90 \mu \mathrm{mol} \mathrm{L}^{-1}$, then this soil would be zero order with respect to $\mathrm{NO}_{3}$. Because denitrification is an anaerobic process, however, $\mathrm{NO}_{3}$ concentrations in anaerobic microsites may not necessarily be the same as $\mathrm{NO}_{3}$ concentrations in the soil solution. Myrold and Tiedje (1985) examined the influence of soil $\mathrm{NO}_{3}$ concentration and diffusion of $\mathrm{NO}_{3}$ into anaerobic denitrifying sites and concluded that agricultural soils with $\mathrm{NO}_{3}$ concentrations well above the apparent $K_{\mathrm{m}}$ could exhibit $\mathrm{NO}_{3}$ limitation. The extent of this effect is dependent on the degree of anaerobiosis and aggregate size distribution.
Despite these diffusion considerations, these investigators concluded that, in their clay loam soil, low $\mathrm{NO}_{3}$ concentrations (i.e., $5 \mathrm{mg} \mathrm{N} \mathrm{kg}^{-1}$ ) soil are not necessarily limiting for denitrification.

Nitrate has also been shown to influence the partitioning of the gaseous end products of denitrification. Blackmer and Bremner (1978) observed that as $\mathrm{NO}_{3}$ concentrations in soil were increased from $20 \mathrm{mg} \mathrm{NO}_{3}-\mathrm{N} \mathrm{kg}^{-1}$ soil to $1020 \mathrm{mg}$ $\mathrm{NO}_{3}-\mathrm{N} \mathrm{kg}^{-1}$ the production of $\mathrm{N}_{2} \mathrm{O}$ relative to $\mathrm{N}_{2}$ produced also increased. Firestone et al. (1979) also observed an increase in $\mathrm{N}_{2} \mathrm{O}$ production relative to $\mathrm{N}_{2}$ with increased $\mathrm{NO}_{3}$ concentration (up to $20 \mathrm{mg} \mathrm{NO}_{3}-\mathrm{N} \mathrm{kg}^{-1}$ soil), but a stronger response was observed with increasing $\mathrm{NO}_{2}{ }^{-}$concentration.

Another factor that may contribute to the varied response of soil $\mathrm{N}_{2} \mathrm{O}$ production to fertilizer additions is $\mathrm{N}$ mineralization. An estimate of $\mathrm{N}$ mineralization can be obtained from soil organic matter content. Schepers and Mosier (1991) proposed that approximately $2 \%$ of the total organic $\mathrm{N}$ in the surface $30 \mathrm{~cm}$ of soil is mineralized annually. Using estimates of $2.7 \mathrm{~g}$ organic $\mathrm{N} \mathrm{kg}^{-1}$ soil and a bulk density of $1.15 \mathrm{~g} \mathrm{~cm}^{-3}$ in the top $15 \mathrm{~cm}$ of the soil at Site 2 of our study (Table 1), we estimate that $\mathrm{N}$ mineralization occurred at a rate of $93.2 \mathrm{~kg} \mathrm{~N} \mathrm{ha}^{-1} \mathrm{yr}^{-1}$ (in the top $15 \mathrm{~cm}$ ). This mineralization estimate is similar to that calculated from the soil inorganic $\mathrm{N}$ dynamics observed in the PVC tubes we installed in 2011. In the check treatment (no added fertilizer), we observed that total mineral $\mathrm{N}\left(\mathrm{NO}_{3}+\right.$ $\mathrm{NH}_{4}$ ) increased at a rate of $0.4 \mathrm{~kg} \mathrm{~N} \mathrm{ha}^{-1} \mathrm{~d}^{-1}$ (top $10 \mathrm{~cm}$ of soil) from DOY 136 to 180 (Fig. 5). After DOY 180, TMN levels decreased, presumably due to corn roots in the soil within the tubes (the PVC tubes were placed approximately $15 \mathrm{~cm}$ from the corn row). Extrapolated across the 145-d sampling period, this rate of $\mathrm{N}$ mineralization would have resulted in the production of $58 \mathrm{~kg} \mathrm{~N} \mathrm{ha}^{-1}$ in the top $10 \mathrm{~cm}$. This rate of $\mathrm{N}$ mineralization in the check plots is not unreasonable, given the fact that in 2011 the corn yield in the unfertilized check plots averaged $8450 \mathrm{~kg}$ grain ha ${ }^{-1}\left(\mathrm{SD}=607 \mathrm{~kg} \mathrm{ha}^{-1}\right)$. Using a value of $0.014 \mathrm{~g} \mathrm{~N} \mathrm{~g}^{-1}$ grain, we calculated that grain $\mathrm{N}$ uptake in the check plots was $118(\mathrm{SD}=8.5) \mathrm{kg} \mathrm{N} \mathrm{ha}^{-1}$. Thus, inorganic $\mathrm{N}$ produced from the mineralization of soil organic matter may represent a significant $\mathrm{N}$ pool fueling $\mathrm{N}_{2} \mathrm{O}$ production in our soils.

The temporal characteristics of soil $\mathrm{NO}_{3}$ dynamics are another complicating factor in the assessment of the effects of fertilizer sources on $\mathrm{N}_{2} \mathrm{O}$ production. The rationale underlying the use of enhanced fertilizers to reduce $\mathrm{N}_{2} \mathrm{O}$ emissions is based on the assumption that $\mathrm{NO}_{3}$ will not be available for denitrification until a sufficient crop sink is established. Rainfall (or irrigation) is a primary determinant of soil $\mathrm{N}_{2} \mathrm{O}$ emissions, thus when the timing of precipitation events coincides with conditions favorable for denitrification (available $\mathrm{C}$ and sufficient $\mathrm{NO}_{3}$ ), peaks of $\mathrm{N}_{2} \mathrm{O}$ emissions can occur. Peak $\mathrm{N}_{2} \mathrm{O}$ emissions events have been observed in response to rainfall events occurring soon after spring fertilization with conventional fertilizers (Baggs et al., 2003; Parkin and Kaspar, 2006; Pelster et al., 2011). In studies where controlled-release fertilizers delayed $\mathrm{NO}_{3}$ formation, however, higher $\mathrm{N}_{2} \mathrm{O}$ emissions events occurred later in the growing season in response to precipitation events (Halvorson and DelGrosso, 2012; Sistani et al., 2011; Venterea et al., 2011). In our study, changes in cumulative $\mathrm{N}_{2} \mathrm{O}$ emissions in 2011 (the only year in which soil inorganic $\mathrm{N}$ concentrations were monitored) seemed to mirror changes in soil $\mathrm{NO}_{3}$. From DOY 
137 to 171, cumulative $\mathrm{N}_{2} \mathrm{O}$ emissions from the ESN treatment were not significantly different from the check; however, at DOY $178, \mathrm{~N}_{2} \mathrm{O}$ emissions in the ESN treatment sharply increased. The peak $\mathrm{N}_{2} \mathrm{O}$ emission event in 2011 was observed on DOY 198. The ultimate effect on cumulative seasonal $\mathrm{N}_{2} \mathrm{O}$ emissions will depend on the relative magnitudes of the early-season $\mathrm{N}_{2} \mathrm{O}$ emissions that may occur in conventionally fertilized sites vs. late-season $\mathrm{N}_{2} \mathrm{O}$ emissions that may occur when EEFs are used.

Further complicating interpretation of the effects of EEFs fertilizers on $\mathrm{N}_{2} \mathrm{O}$ emissions is the fact that soil $\mathrm{N}_{2} \mathrm{O}$ production can result from disparate microbial processes: namely, autotrophic nitrification, heterotrophic nitrification, and denitrification. In a laboratory study investigating the effects of soil water-filled pore space (WFPS) on $\mathrm{N}_{2} \mathrm{O}$ production from nitrification and denitrification, Bateman and Baggs (2005) observed that: (i) $\mathrm{N}_{2} \mathrm{O}$ production from heterotrophic nitrification was minor, (ii) $\mathrm{N}_{2} \mathrm{O}$ production from nitrification dominated total $\mathrm{N}_{2} \mathrm{O}$ production at WFPS between 35 and 60\% (accounting for 63.3-81.5\% of the total $\mathrm{N}_{2} \mathrm{O}$ produced), but at $70 \%$ WFPS, denitrification accounted for $100 \%$ of the $\mathrm{N}_{2} \mathrm{O}$ production. These results are similar to those observed by Skiba et al. (1993), who observed that nitrification was the dominant process influencing $\mathrm{N}_{2} \mathrm{O}$ emissions under dry soil conditions but that denitrification was the dominant source of $\mathrm{N}_{2} \mathrm{O}$ under wet soil conditions.

The efficacy of EEFs in reducing $\mathrm{N}_{2} \mathrm{O}$ emissions may also be affected by the presence of plants through two competing mechanisms. Root exudates may provide a $\mathrm{C}$ source to denitrifying organisms, yet plant roots may compete for the available soil $\mathrm{NO}_{3}$. Stefanson (1972) found that growing wheat (Triticum aestivum L.) plants increased both denitrification and $\mathrm{N}_{2} \mathrm{O}$ production in soil containing approximately $100 \mathrm{mg} \mathrm{NO}_{3}-\mathrm{N} \mathrm{kg}^{-1}$ soil. Conversely, Haider et al. (1985) found no stimulation of denitrification in the presence of growing corn plants where soil $\mathrm{NO}_{3}$ concentrations were $10 \mathrm{mg} \mathrm{NO}_{3}-\mathrm{N} \mathrm{kg}^{-1}$ soil. Smith and Tiedje (1979) found that the presence of growing plants (both corn and orchardgrass [Dactylis glomerata L.]), stimulated denitrification when $\mathrm{NO}_{3}$ concentrations were high but that denitrification was reduced in the presence of plants at low $\mathrm{NO}_{3}$ concentrations. Thus, denitrification is differentially affected by the temporal dynamics of plant root development (and the resulting $\mathrm{C}$ source supply in the form of exudates vs. increased $\mathrm{NO}_{3}$ uptake) in relation to soil $\mathrm{NO}_{3}$ supply from the fertilizer source.

In rainfed regions, temporal variations in precipitation in relation to soil inorganic $\mathrm{N}$ levels may be the key determinant of the magnitude of cumulative $\mathrm{N}_{2} \mathrm{O}$ losses. Growing-season $\mathrm{N}_{2} \mathrm{O}$ emissions are typically characterized by low "background" emissions punctuated by rainfall-induced peak emissions events. During times of background emissions, nitrification may be the dominant $\mathrm{N}_{2} \mathrm{O}$-producing process, but peak emission events may be dominated by denitrification. The impact of EEFs will be due, in part, to $\mathrm{NH}_{4}$ and $\mathrm{NO}_{3}$ availability during these peak and non-peak times, and the ultimate effect on cumulative seasonal $\mathrm{N}_{2} \mathrm{O}$ emissions will be a reflection of the combined magnitudes and durations of $\mathrm{N}_{2} \mathrm{O}$ emissions during the non-peak (nitrification) and peak (denitrification) times. Management of soil $\mathrm{N}_{2} \mathrm{O}$ emissions through the use of EEFs to control inorganic soil $\mathrm{N}$ levels is affected by many interacting factors, including: (i) the timing and concentration of $\mathrm{NH}_{4}$ and $\mathrm{NO}_{3}$ release, (ii) the relative activities of nitrification and denitrification, (iii) the strength of the plant sink, (iv) the partitioning of the denitrification end products between $\mathrm{N}_{2} \mathrm{O}$ and $\mathrm{N}_{2}$, and (v) other mechanisms of inorganic $\mathrm{N}$ loss (i.e., $\mathrm{NH}_{3}$ volatilization and $\mathrm{NO}_{3}$ leaching).

\section{CONCLUSIONS}

These studies were conducted to evaluate the effects of EEFs on growing-season $\mathrm{N}_{2} \mathrm{O}$ emissions in central Iowa. In 2 of the $3 \mathrm{yr}$ (2010 and 2011), there was no difference in cumulative $\mathrm{N}_{2} \mathrm{O}$ emissions among fertilizer types, but fertilizer treatments were significantly higher than the control plots (no fertilizer). In 2009, cumulative $\mathrm{N}_{2} \mathrm{O}$ emissions from the polymer-coated urea (ESN) treatment was significantly greater than the UAN and UAN $+\mathrm{Ag}$ treatments. Control of $\mathrm{N}_{2} \mathrm{O}$ emissions by regulation of soil inorganic $\mathrm{N}$ afforded by EEFs may be of limited value in regions where $\mathrm{N}_{2} \mathrm{O}$ emissions are episodic and stimulated primarily by rainfall events.

\section{ACKNOWLEDGMENTS}

We are grateful to Agrium, Agrotain, Nutrisphere, and the Foundation for Agricultural Research for their support of this project in Ames and our companion sites at the other locations. We also thank Richard Hartwig for management of the field plots and Otis Smith, who assisted in the data collection.

\section{REFERENCES}

Akiyama, H., X. Yan, and K. Yagi. 2010. Evaluation of effectiveness of enhancedefficiency fertilizers as mitigation options for $\mathrm{N}_{2} \mathrm{O}$ and $\mathrm{NO}$ emissions from agricultural soils: Meta-analysis. Global Change Biol. 16:1837-1846. doi:10.1111/j.1365-2486.2009.02031.x

Andrews, W.F., and R.O. Diderikson. 1981. Soil survey of Boone County, Iowa. U.S. Gov. Print. Office, Washington, DC.

Arnold, S., T.B. Parkin, J.W. Doran, and A.R. Mosier. 2001. Automated gas sampling system for laboratory analysis of $\mathrm{CH}_{4}$ and $\mathrm{N}_{2} \mathrm{O}$. Commun. Soil Sci. Plant Anal. 32:2795-2807. doi:10.1081/CSS-120000962

Baggs, E.M., M. Stevenson, M. Pihlatie, A. Regar, H. Cook, and G. Cadisch. 2003. Nitrous oxide emissions following application of residues and fertilizer under zero and conventional tillage. Plant Soil 254:361-370. doi:10.1023/A:1025593121839

Bateman, E.J., and E.M. Baggs. 2005. Contributions of nitrification and denitrification to $\mathrm{N}_{2} \mathrm{O}$ emissions from soils at different water-filled pore space. Biol. Fertil. Soils 41:379-388. doi:10.1007/s00374-005-0858-3

Blackmer, A.M., and J.M. Bremner. 1978. Inhibitory effect of nitrate on reduction of $\mathrm{N}_{2} \mathrm{O}$ to $\mathrm{N}_{2}$ by soil microorganisms. Soil Biol. Biochem. 10:187-191. doi:10.1016/0038-0717(78)90095-0

Betlach, M.R., and J.M. Tiedje. 1981. Kinetic explanation for accumulation of nitrite, nitric oxide, and nitrous oxide during bacterial denitrification. Appl. Environ. Microbiol. 42:1074-1084.

Bouwman, A.F., L.J.M. Boumans, and N.H. Batjes. 2002. Emissions of $\mathrm{N}_{2} \mathrm{O}$ and NO from fertilized fields: Summary of available measurement data. Global Biogeochem. Cycles 16:6-1-6-13. doi:10.1029/2001GB001811

Box, G.E.P., and G.W. Jenkins. 1976. Time series analysis: Forecasting and control. Holden-Day, San Francisco.

Christensen, S., and J.M. Tiedje. 1988. Sub-parts-per-billion nitrate method: Use of an $\mathrm{N}_{2} \mathrm{O}$-producing denitrifier to convert $\mathrm{NO}_{3}{ }^{-}$or ${ }^{15} \mathrm{NO}_{3}{ }^{-}$to $\mathrm{N}_{2} \mathrm{O}$. Appl. Environ. Microbiol. 54:1409-1413.

Firestone, M.K., M.S. Smith, R.B. Firestone, and J.M. Tiedje. 1979. The influence of nitrate, nitrite, and oxygen on the composition of gaseous products of denitrification in soil. Soil Sci. Soc. Am. J. 43:1140-1144. doi:10.2136/ sssaj1979.03615995004300060016x

Haider, K., A. Mosier, and O. Heinemeyer. 1985. Phytotron experiments to evaluate the effect of growing plants on denitrification. Soil Sci. Soc. Am. J. 49:636-641. doi:10.2136/sssaj1985.03615995004900030022x 
Halvorson, A.D., and S.J. Del Grosso. 2012. Nitrogen source and placement effects on soil nitrous oxide emissions from no-till corn. J. Environ. Qual. 41:1349-1360. doi:10.2134/jeq2012.0129

Halvorson, A.D., S.J. Del Grosso, and F. Alluvione. 2010a. Nitrogen source effects on nitrous oxide emissions from irrigated no-till corn. J. Environ. Qual. 39:1554-1562. doi:10.2134/jeq2010.0041

Halvorson, A.D., S.J. Del Grosso, and F. Alluvione. 2010b. Tillage and inorganic nitrogen source effects on nitrous oxide emissions from irrigated cropping systems. Soil Sci. Soc. Am. J. 74:436-445. doi:10.2136/sssaj2009.0072

Halvorson, A.D., S.J. Del Grosso, and C.P. Jantalia. 2011. Nitrogen source effects on soil nitrous oxide emissions from strip-till corn.J. Environ. Qual. 40:1775-1786. doi:10.2134/jeq2011.0194

Halvorson, A.D., S.J. Del Grosso, and C.A. Ruele. 2008. Nitrogen, tillage, and crop rotation effects on nitrous oxide emissions from irrigated cropping systems. J. Environ. Qual. 37:1337-1344. doi:10.2134/jeq2007.0268

Halvorson, A.D., C.S. Snyder, A.D. Blaylock, and S.J. Del Grosso. 2013. Enhanced-efficiency nitrogen fertilizers: Potential role in nitrous oxide emission mitigation. Agron. J. (this issue).

Hart, S.C., J.M. Stark, E.A. Davidson, and M.K. Firestone. 1994. Nitrogen mineralization, immobilization, and nitrification. In: R.W Weaver et al., editors, Methods of soil analysis. Part 2. Microbiological and biochemical properties. SSSA Book Ser. 5. SSSA, Madison, WI. p. 985-1018. doi:10.2136/sssabookser5.2.c42

Hatfield, J.L., and T.B. Parkin. 2013. Enhanced efficiency fertilizers: Effect on agronomic performance in Iowa. Agron. J. (this issue).

Hoben, J.P., R.J. Gehl, N. Millar, P.R. Grace, and G.P. Robertson. 2011. Nonlinear nitrous oxide $\left(\mathrm{N}_{2} \mathrm{O}\right)$ response to nitrogen fertilizer in on-farm corn crops of the U.S. Midwest. Global Change Biol. 17:1140-1152. doi:10.1111/j.1365-2486.2010.02349.x

Hutchinson, G.L., and A.R. Mosier. 1981. Improved soil cover method for field measurement of nitrous oxide fluxes. Soil Sci. Soc. Am. J. 45:311-316. doi:10.2136/sssaj1981.03615995004500020017x

Jumadi, O., Y. Hala, A. Muis, A. Ali, M. Palennari, K. Yagi, and K. Inubushi. 2008. Influence of chemical fertilizers and a nitrification inhibitor on greenhouse gas fluxes in a corn (Zea mays L.) field in Indonesia. Microbes Environ. 23:29-34. doi:10.1264/jsme2.23.29

Keeney, D.R., and D.W. Nelson. 1982. Nitrogen-Inorganic forms. In: A.L. Page et al., editors, Methods of soil analysis. Part 2. 2nd ed. Agron. Monogr. 9. ASA and SSSA, Madison, WI. p. 643-698. doi:10.2134/ agronmonogr9.2.2ed.c33

Maag, M., M. Malinovsky, and S.M. Nielsen. 1997. Kinetics and temperature dependence of potential denitrification in riparian soils. J. Environ. Qual. 26:215-223. doi:10.2134/jeq1997.00472425002600010031x

Magalhães, A.M.T., P.M. Chalk, and W.M. Strong. 1984. Effect of nitrapyrin on nitrous oxide emission from fallow soils fertilized with anhydrous ammonia. Fert. Res. 5:411-421. doi:10.1007/BF01049121

Malhi, S.S., R.L. Lemke, Z. Wang, R. Farrell, and B.S. Chhabra. 2006. Tillage, nitrogen and crop residue effects on crop yield and nutrient uptake, soil quality and greenhouse gas emissions. Soil Tillage Res. 90:171-183. doi:10.1016/j.still.2005.09.001

McSwiney, C.P., and G.P. Robertson. 2005. Nonlinear response of $\mathrm{N}_{2} \mathrm{O}$ flux to incremental fertilizer addition in a continuous maize ( $\mathrm{Z}_{e a}$ mays L.) cropping system. Global Change Biol. 11:1712-1719. doi:10.1111/j.1365-2486.2005.01040.x

Mead, R. 1988. The design of experiments: Statistical principles for practical applications. Cambridge Univ. Press, New York.

Mosier, A.R., A.D. Halvorson, C.A. Reule, and X.J. Liu. 2006. Net global warming potential and greenhouse gas intensity in irrigated cropping systems in northeastern Colorado. J. Environ. Qual. 35:1584-1598. doi:10.2134/ jeq2005.0232
Murray, R.E., L.L. Parsons, and M.S. Smith. 1989. Kinetics of nitrate utilization by mixed populations of denitrifying bacteria. Appl. Environ. Microbiol. 55:717-721.

Myrold, D.D., and J.M. Tiedje. 1985. Diffusional constraints on denitrification in soil. Soil Sci. Soc. Am. J. 49:651-657. doi:10.2136/ sssaj1985.03615995004900030025x

Nelson, D.W., and L.E. Sommers. 1996. Total carbon, organic carbon and organic matter. In: D.L. Sparks, editor, Methods of soil analysis. Part 3. SSSA Book Ser. 5. SSSA and ASA, Madison, WI. p. 961-1010. doi:10.2136/sssabookser5.3.c34

Parkin, T.B. 2008. Effect of sampling frequency on estimates of cumulative nitrous oxide emissions. J. Environ. Qual. 37:1390-1395. doi:10.2134/ jeq2007.0333

Parkin, T.B., and T.C. Kaspar. 2006. Nitrous oxide emissions from corn-soybean systems in the Midwest. J. Environ. Qual. 35:1496-1506. doi:10.2134/ jeq2005.0183

Parkin, T.B., and R.T. Venterea. 2010. Chamber-based trace gas flux measurements. In: R.F. Follett, editor, Sampling protocols. USDA-ARS, Washington, DC. p. 3-1- 3-39. www.ars.usda.gov/SP2UserFiles/Program/212/ Chapter\%203.\%20GRACEnet\%20Trace\%20Gas\%20Sampling\%20Protocols.pdf (accessed 11 Apr. 2013).

Parkin, T.B., R.T. Venterea, and S.K. Hargreaves. 2012. Calculating the detection limits of chamber-based soil greenhouse gas flux measurements. J. Environ. Qual. 41:705-715. doi:10.2134/jeq2011.0394

Pelster, D.E., F. Larouche, P. Rochette, M.H. Chantigny, S. Allaire, and D.A. Angers. 2011. Nitrogen fertilization but not soil tillage affects nitrous oxide emissions from a clay loam soil under a maize-soybean rotation. Soil Tillage Res. 115-116:16-26. doi:10.1016/j.still.2011.06.001

Robertson, G.P., D. Wedin, P.M. Groffman, J.M. Blair, E.A. Holland, K.J. Nadelhoffer, and D. Harris. 1999. Soil carbon and nitrogen availability: Nitrogen mineralization, nitrification and carbon turnover. In: G.P. Robertson et al., editors, Standard soil methods for long term ecological research. Oxford Univ. Press, New York. p. 258-271.

Schepers, J.S., and A.R. Mosier. 1991. Accounting for nitrogen in nonequilibrium soil-crop systems. In: R.F. Follett et al., editors, Managing nitrogen for groundwater quality and farm profitability. SSSA, Madison, WI. P. 125-138. doi:10.2136/1991.managingnitrogen.c6

Sistani, K.R., M. Jn-Baptiste, N. Lovanh, and K.L. Cook. 2011. Atmospheric emissions of nitrous oxide, methane, and carbon dioxide from different nitrogen fertilizers. J. Environ. Qual. 40:1797-1805. doi:10.2134/ jeq2011.0197

Skiba, U., K.A. Smith, and D. Fowler. 1993. Nitrification and denitrification as sources of nitric oxide and nitrous oxide in a sandy loam soil. Soil Biol. Biochem. 25:1527-1536. doi:10.1016/0038-0717(93)90007-X

Smith, M.S., and J.M. Tiedje. 1979. The effect of roots on soil denitrification. Soil Sci. Soc. Am. J. 43:951-955. doi:10.2136/ sssaj1979.03615995004300050027x

Snyder, C.S., T.W. Bruulsema, T.L. Jensen, and P.E. Fixen. 2009. Review of greenhouse gas emissions from crop production systems and fertilizer management effects. Agric. Ecosyst. Environ. 133:247-266. doi:10.1016/j. agee.2009.04.021

Stefanson, R.C. 1972. Soil denitrification in sealed plant-soil systems: I. Effect of plants, soil water content and soil organic matter content. Plant Soil 33:113-127. doi:10.1007/BF01578484

USEPA. 2013. Inventory of U.S. greenhouse gas emissions and sinks: 19902011. USEPA Climate Change Div., Washington, DC. http://epa.gov/climatechange/emissions/usinventoryreport.html (accessed 23 Mar. 2013).

Venterea, R.T., B. Maharjan, and M.S. Dolan. 2011. Fertilizer source and tillage effects on yield-scaled nitrous oxide emissions in a corn cropping system. J. Environ. Qual. 40:1521-1531. doi:10.2134/jeq2011.0039 